\title{
9. BOREHOLE WATER STUDIES, HOLE 418A ${ }^{1}$
}

\author{
Joris M. Gieskes, Scripps Institution of Oceanography, La Jolla, California ${ }^{2}$ \\ Stan Hart, Department of Earth and Space Sciences, Massachusetts Institute of Technology, Cambridge, \\ Massachusetts ${ }^{3}$ \\ and \\ Gail Peretsman, Ocean Drilling Program, Texas A\&M University, College Station, Texas ${ }^{4}$
}

\begin{abstract}
Ocean Drilling Program Leg 102 returned to Hole 418A 8 yr after it was originally drilled and retrieved a borehole water sample at a depth of ca. $350 \mathrm{~m}$ into basaltic basement. Chemical analysis for the major constituents and strontium isotopes indicates that substantial changes in the chemical composition of originally introduced surface seawater are principally due to diffusive exchange with surrounding formation waters. These changes include an increase in dissolved calcium and decreases in dissolved magnesium, sodium, and potassium, as well as in the ${ }^{87} \mathrm{Sr} /{ }^{86} \mathrm{Sr}$ ratio of dissolved strontium. Extrapolation of the data to zero magnesium yields dissolved calcium concentrations predicted by a diffusive exchange model, which is consistent with high dissolved calcium concentrations observed at other sites that show complete depletion of dissolved magnesium in the interstitial waters in sediments intercalated in basaltic basement.
\end{abstract}

\section{INTRODUCTION}

During the 15 yr of the Deep Sea Drilling Project (DSDP) a large body of information was developed on the chemical composition of dissolved solids in the interstitial waters of marine sediments. Concentration-depth gradients of major constituents such as $\mathrm{Ca}^{2+}, \mathrm{Mg}^{2+}, \mathrm{K}^{+}$, and $\mathrm{Na}^{+}$indicate, in many cases, that changes in these constituents are the result of low-temperature alteration of the underlying basalt of Layer 2 . The basalt is a sink for $\mathrm{K}^{+}, \mathrm{Mg}^{2+}$, and $\mathrm{Na}^{+}$, as well as for ${ }^{18} \mathrm{O}\left(\mathrm{H}_{2} \mathrm{O}\right)$, whereas the basalt serves as a source for $\mathrm{Ca}^{2+}$ (Lawrence at al., 1975; Lawrence and Gieskes, 1981; Gieskes and Lawrence, 1981; Gieskes, 1983). McDuff (1981) argued that to maintain these concentration gradients, circulation of formation waters must occur over considerable time in the oceanic crust, well beyond the period of so-called sealing of the crust by the accumulation of a thick, impermeable (to flow) sediment cover (Anderson et al., 1977). After the crust is sealed by sediment, transport of ions through Layer 1 to/from Layer 2 becomes diffusive (McDuff, 1981). Lawrence and Gieskes (1981) concluded from oxygen isotope mass-balance calculations that substantial alteration of Layer 2 must occur over a long period of time, again in agreement with observations of Muehlenbachs and Clayton (1976).

Hitherto, there have been few chances to verify the preceding ideas, which were developed from sediment interstitial-water data, for the chemistry of basalt formation waters. Interstitialwater samples have been obtained from clay layers interbedded in basalt from Site 446 in the Daito Basin (Gieskes and Johnson, 1981), Site 528 on the Walvis Ridge (Gieskes et al., 1984), and Site 555 on the Rockall Plateau (Gieskes and Johnston, 1984). Typically, the chemical compositions were completely depleted in $\mathrm{Mg}^{2+}$ and had very low concentrations of $\mathrm{K}^{+}$, accom-

${ }^{1}$ Salisbury, M. H., Scott, J. H., et al., 1988. Proc. ODP, Sci. Results, 102: College Station, TX, (Ocean Drilling Program).

2 Address: Scripps Institution of Oceanography, La Jolla, CA 92093.

${ }^{3}$ Address: Department of Earth and Space Sciences, Massachusetts Institute of Technology, Cambridge, MA 02139.

4 Address: Ocean Drilling Program, Texas A\&M University, College Station, panied by large increases in dissolved $\mathrm{Ca}^{2+}$. Even though $\mathrm{Mg}^{2+}$ and $\mathrm{K}^{+}$concentrations are finite at the base of many holes, an important consideration of these observations is that the concentrations will be close to zero in the formation waters of the underlying basalt. Only relatively fast diffusive exchange through porous sediment to the overlying ocean will allow nonzero concentrations of these constituents just above the sediment/basalt interface. At sites with younger oceanic crust, seawater that has been introduced only recently into the basalt leads to little change in the chemical composition, of which Site 505 is an excellent example (Mottl et al., 1983).

During the last few years, reentry of previously drilled holes, particularly DSDP Hole 395A near the Mid-Atlantic Ridge and Hole 504B near the Costa Rica Rift, has made possible study of the composition of borehole waters in deep oceanic crust that is relatively young in age (1-5 yr). It was thought that the composition of formation waters surrounding these holes might be inferred from these studies. McDuff (1984) described the chemical composition of a borehole sample obtained in Hole 395A at a sub-bottom depth of $543 \mathrm{~m}$, in the zone where no further drawdown of bottom water has been observed (Becker et al., 1984). McDuff inferred from the small increase in $\mathrm{Ca}^{+}$and the relatively large decreases in $\mathrm{Mg}^{2+}, \mathrm{K}^{+}$, and $\mathrm{SO}_{4}^{2-}$ that these changes in chemical composition were caused by reactions in the basement and that the chemical signals of basement waters were transferred by convective and/or diffusive transport to the pumped-down surface waters filling the borehole. Relatively small increases in calcium were explained in terms of calcium carbonate precipitation, which has been observed extensively as vein fillings at Site 395 . Decreases in sulfate could not be explained readily and were considered to be due to sulfate-reduction processes occurring in the overlying sediments that seawater percolated through prior to entering the basalt. A problem with this explanation is that Site 395 sediment does not show significant depletions in sulfate at the present time and differences in the past are not likely.

Hole 504B has been returned to several times since it was originally drilled, and extensive studies of the borehole fluids have been conducted (Mottl et al., 1983, 1985; Gieskes et al., 1986). Although evidence regarding the cause of these changes 
is still considered ambiguous, Mottl et al. (1985) and Gieskes et al. (1986) proposed various scenarios ranging from communication with the surrounding rocks by transport from formation waters to reaction between borehole waters and wall rocks. These authors, however, could not reach any definite conclusions with respect to the actual causes of the observed changes in chemistry. Perhaps the Ocean Drilling Program (ODP) Leg 111 reentry of this hole may answer some of these questions.

Reentering Hole $418 \mathrm{~A}$ was considered an important addition to the number of holes reentered to date, particularly because Hole $418 \mathrm{~A}$ was thought to be closed off from the overlying seawater by sediment bridges in the deeper, uncased section of the hole. This is especially likely because the hole was cased only to $71 \mathrm{~m}$ in the sediment. Thus, surface seawater pumped down the hole has been in a closed system for the last $8 \mathrm{yr}$, ample time for reaction and/or exchange with the surrounding rocks. This report presents data on two samples of borehole fluids obtained from Hole 418A during ODP Leg 102.

\section{Previous Hydrogeochemical Studies at Sites 417 and 418}

During Legs 51-53, samples were obtained at Sites 417 and 418 for interstitial-water studies. The data obtained for dissolved calcium and magnesium are summarized in Figure 1 (Gieskes and Reese, 1980). Gieskes and Reese suggested that the gradients of $\mathrm{Ca}^{2+}$ and $\mathrm{Mg}^{2+}$ were essentially diffusive in nature (i.e., the major source of $\mathrm{Ca}^{2+}$ and the major sink for $\mathrm{Mg}^{2+}$ were located not in the sediment, but rather in the underlying basalt of Layer 2).

The correlation plot for $\mathrm{Ca}^{2+}$ and $\mathrm{Mg}^{2+}$ (Fig. 2) shows a typical ratio of change in these constituents of $\Delta \mathrm{Ca} / \Delta \mathrm{Mg} \sim-1.5$ at both sites. The slight decreases in dissolved sulfate at these sites require depletions of $\mathrm{Na}^{+}$(and $\mathrm{K}^{+}$, as observed) to maintain the charge balance. This is a typical observation for sites in older crust (McDuff, 1978, 1981) and has been explained in terms of uptake of $\mathrm{Na}^{+}$in basalt alteration products after the depletion of $\mathrm{Mg}^{2+}$ in the formation waters (McDuff, 1981).

Lawrence and Gieskes (1981) have observed that at most DSDP sites a good correlation exists between changes in dissolved calcium and changes in $\delta^{18} \mathrm{O}\left(\mathrm{H}_{2} \mathrm{O}\right)$ of the interstitial waters. Data obtained for $\delta^{18} \mathrm{O}$ for the pore waters of Sites 417 and 418 (J. R. Lawrence, pers. comm., 1977) are correlated with $\mathrm{Ca}^{2+}$ in Figure 3. The data indicate a decrease in $\delta^{18} \mathrm{O}$ with increasing $\mathrm{Ca}^{2+}$ with $\Delta \delta^{18} \mathrm{O} / \Delta \mathrm{Ca}^{2+}=-0.06 \% / \mathrm{mM}$, slightly less than the average correlation of $-0.08 \%$ o mM suggested by Lawrence and Gieskes (1981). Nevertheless, mass-balance considerations based on similar depletions in $\delta^{18} \mathrm{O}$ at other sites (Lawrence and Gieskes, 1981) require substantial alteration of volcanic material in Layer 2, and $\delta^{18} \mathrm{O}$ decreases cannot be explained from carbonate or clay-mineral diagenesis in the sediment.

Staudigel and Hart (1985) argue that basalt alteration at Sites 417 and 418 stops after a relatively short time span, less than $15 \mathrm{~m}$.y. Whether this is so or otherwise, the formation waters trapped in the basalt will have a distinctly different composition from that of seawater.

We conclude that the underlying basalt is the main source of dissolved calcium and is a sink for dissolved magnesium at Sites 417 and 418 . In view of the observed decrease in $\delta^{18} \mathrm{O}$, a substantial alteration signal is still present in the formation fluids of Layer 2.

\section{METHODOLOGY}

\section{Sampling}

The Leg 102 sampling procedure used the Barnes-Uyeda insitu interstitial-water sampler. Temperature data were also obtained with this device (c.f., Shipboard Scientific Party, 1986).
A
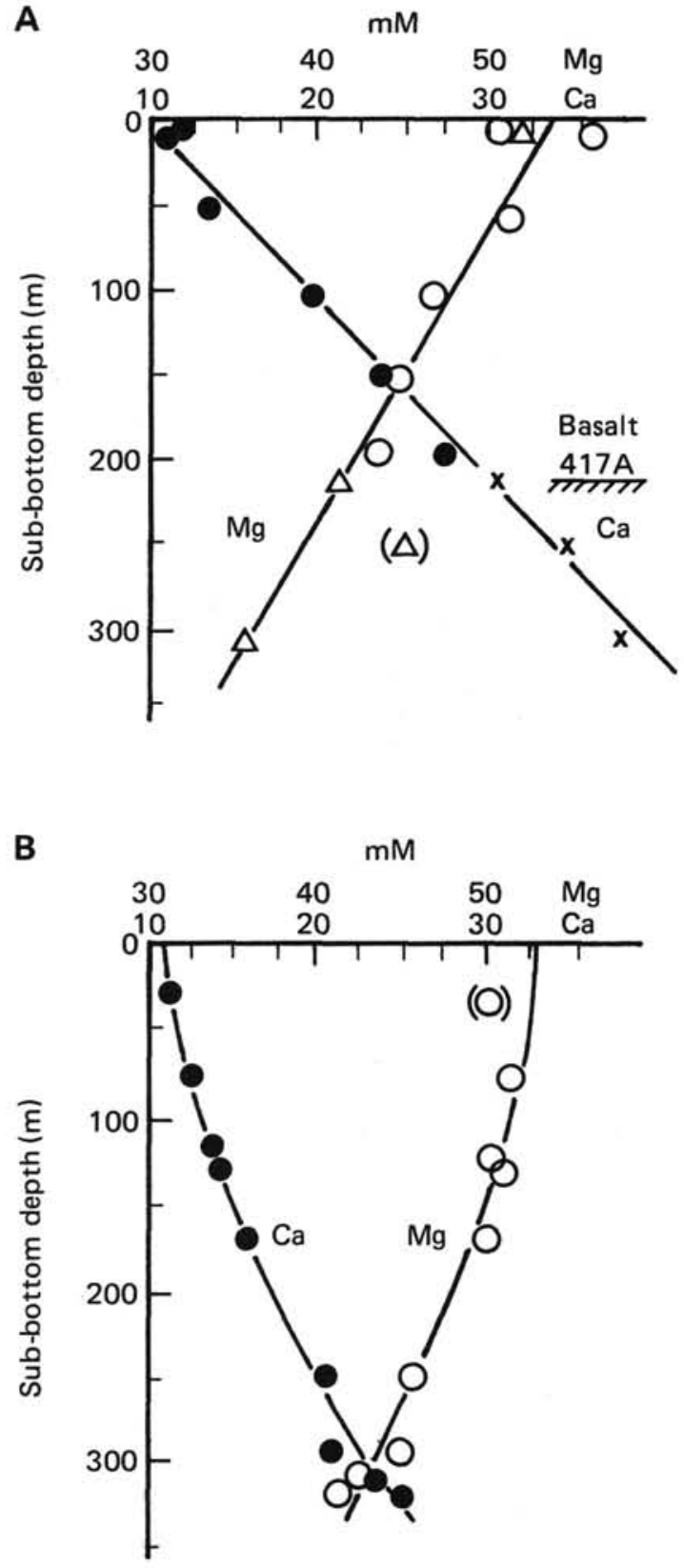

Figure 1. A. $\mathrm{Ca}^{2+}$ and $\mathrm{Mg}^{2+}$ concentration-depth profiles, Holes $417 \mathrm{~A}$ (circles) and 417D (triangles and crosses). $\mathrm{B} . \mathrm{Ca}^{2+}$ and $\mathrm{Mg}^{2+}$ concentration-depth profiles, Site 418 .

Two samples were taken, the first from just below the casing at a sub-bottom depth of approximately $81 \mathrm{~m}$. On retrieval, the probe was covered with sediment, which is clear evidence that the sampler had been in contact with soft sediment, presumably associated with mud collapse in the upper part of the sediment column. The second sample was obtained, again with associated temperature measurements, at a depth of approximately $325 \mathrm{~m}$ within basement. Fine suspended mud was present only in the overflow tube of the sampling device, and samples in the stainless-steel coil were essentially free of particulates. The suspended material consisted of a mixture of calcite and the clay minerals smectite, kaolinite, and illite (M. A. Holmes, pers. comm., 1985). The careful lowering of the pipe after the device was seated in the bottom of the pipe has especially convinced us that we recovered two representative samples. Temperature measurements 


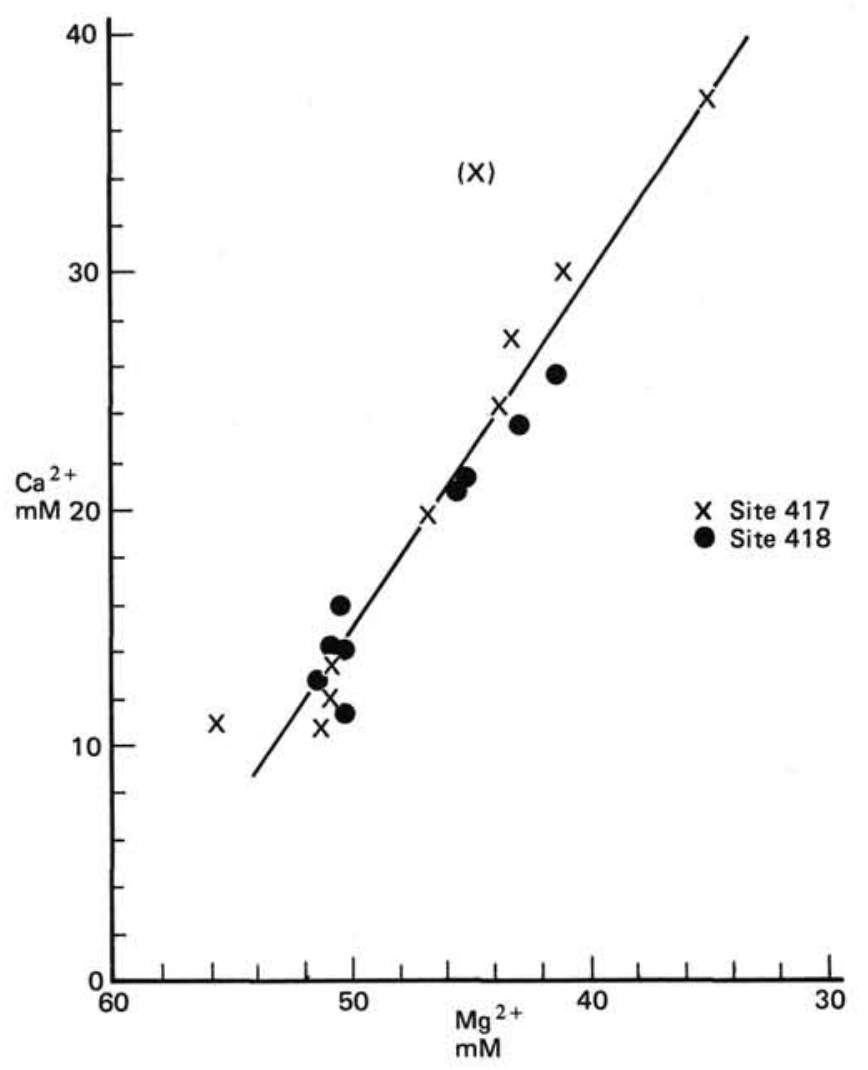

Figure 2. Correlation between $\mathrm{Ca}^{2+}$ and $\mathrm{Mg}^{2+}$ in interstitial waters of Sites 417 and 418 (Gieskes and Reese, 1980); $\Delta \mathrm{Ca} / \Delta \mathrm{Mg}=-1.45 \pm 0.1$.

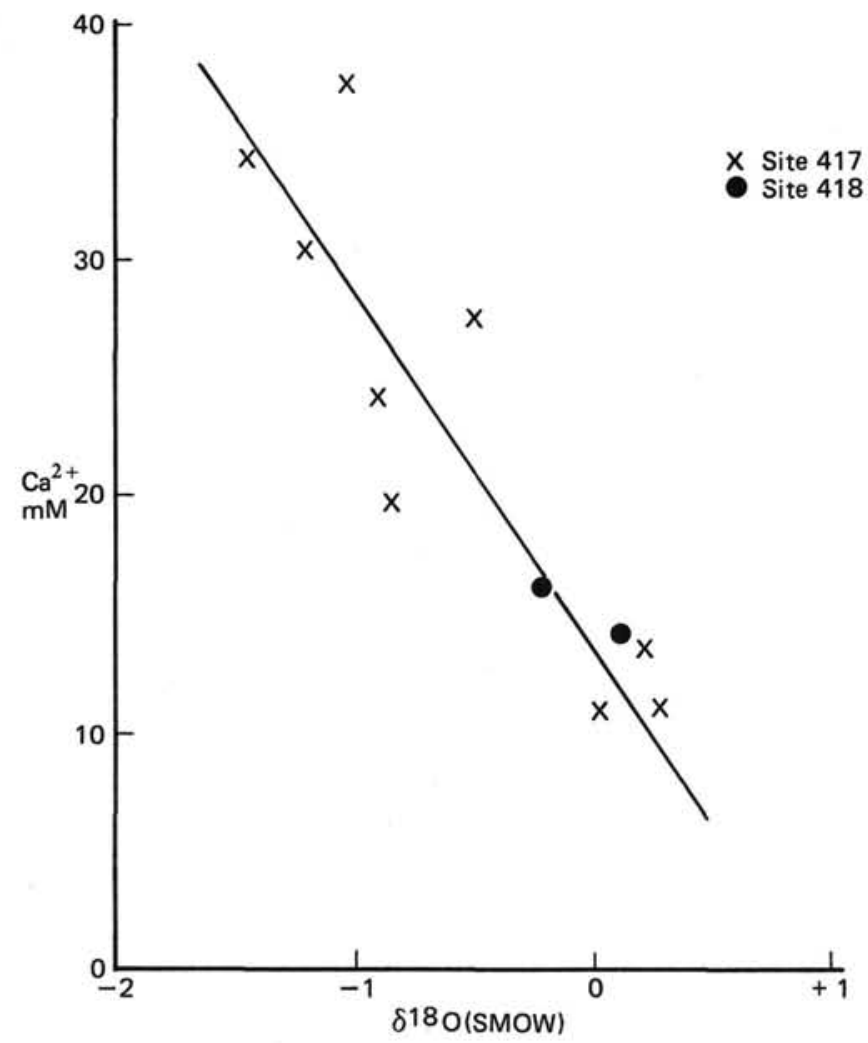

Figure 3. $\delta^{18} \mathrm{O}\left(\mathrm{H}_{2} \mathrm{O}\right)$ vs. $\mathrm{Ca}^{2+}$ in interstitial waters of Sites 417 and 418 . SMOW $=$ standard mean ocean water. in the deeper part of the hole, however, do suggest that some downhole mixing may have occurred as a result of surface seawater having been pumped to a depth of $50 \mathrm{~m}$ above the sampling depth.

\section{Chemical Analysis}

Methodologies included the following:

$\mathrm{pH}$, alkalinity Semiautomatic titration with Metrohm titrator; alkalinity $\pm 3 \%$

Ca EGTA titration (Gieskes and Peretsman, 1986), but with the precautionary addition of $95 \%$ of EGTA prior to buffer addition; accuracy $\pm 1 \%$

$\mathrm{Mg} \quad$ EDTA titration for total alkaline earths (Gieskes, 1974) and subsequent subtraction of $\mathrm{Ca}$; accuracy $\pm 1 \%$

$\mathrm{SO}_{4} \quad$ Dionex ion chromatography; accuracy $\pm 2 \%$

$\mathrm{NO}_{3} \quad$ Colorimetry following $\mathrm{Cd}$ reduction and subsequent determination of $\mathrm{NO}_{2}$ by diazotization; accuracy $\pm 2 \mu \mathrm{M}$ using $0.5-\mathrm{cm}^{3}$ samples

$\mathrm{H}_{4} \mathrm{SiO}_{4} \quad$ Colorimetry with molybdate blue method; accuracy $\pm 1 \%$

$\mathrm{Cl}$ Mohr titration with silver nitrate; accuracy $\pm 0.3 \%$

$\mathrm{Fe} \quad$ Colorimetry using orthophenantroline method; accuracy $\pm 3 \%$

$\mathrm{NH}_{4} \quad$ Colorimetry with phenol-hypochlorite method; accuracy $\pm 3 \mu \mathrm{M}$ using $0.5-\mathrm{cm}^{3}$ samples

K

Dionex ion chromatography and atomic absorption; accuracy $\pm 5 \%$

$\mathrm{Li} \quad$ Atomic absorption; accuracy $\pm 5 \%$

$\mathrm{Sr} \quad$ Atomic absorption; isotope dilution; accuracy

${ }^{87} \mathrm{Sr} /{ }^{86} \mathrm{Sr}$ $\pm 3 \%$

Mass spectrometry

\section{RESULTS}

In this study we analyzed five samples: surface seawater, which is relevant because it was the original water introduced to the hole; Barnes No. 1 (BAW-1); and Barnes No. 2 (BAW-2), which was sampled from the first stainless-steel coil (A), the second stainless-steel coil (B), and the overflow tube (diluted with distilled water).

The data for these samples are presented in Tables 1 and 2 . In Table 3 we present the changes in the chemistry with respect to surface seawater. It should be noted that surface seawater has a considerably higher chlorosity than bottom water $(\mathrm{Cl}=$ $590 \mathrm{mM}$ vs. $\mathrm{Cl}=557 \mathrm{mM}$, a difference of about $5.9 \%$ ) and is thus readily distinguishable from bottom water. In the diluted BAW-2 sample, uptake of clay present in the sample probably resulted in dissolved silica values that are low in comparison to those of the BAW-2-A and BAW-2-B samples.

\section{DISCUSSION}

\section{Sample BAW-1}

The BAW-1 sample was taken in soft mud, about $9 \mathrm{~m}$ below the casing of Hole 418A. Prior to reentry, surface seawater was pumped down the pipe, but pumping was halted on reentry. After initially lowering the pipe approximately $40 \mathrm{~m}$, the BarnesUyeda tool was lowered on the sand line and seated in the bottom of the pipe. Subsequently the pipe was lowered to $10 \mathrm{~m}$ below the casing, or $\sim 80 \mathrm{~m}$ below seafloor (mbsf). The sample showed evidence of having been in soft mud, presumably caused by a previous collapse of the hole. Temperature data taken in the 
Table 1. Chemical composition of borehole waters, Site 418.

\begin{tabular}{|c|c|c|c|c|c|c|c|c|c|c|c|c|c|}
\hline Sample & $\begin{array}{c}\mathrm{T} \\
\left({ }^{\circ} \mathrm{C}\right)\end{array}$ & $\mathrm{pH}$ & $\begin{array}{c}\text { Alkalinity } \\
(\mathrm{mM})\end{array}$ & $\underset{(\mathrm{mM})}{\mathrm{Ca}}$ & $\underset{(\mathrm{mM})}{\mathrm{Mg}}$ & $\underset{(\mathrm{mM})}{\mathrm{Cl}}$ & $\begin{array}{l}\mathrm{SO}_{4} \\
(\mathrm{mM})\end{array}$ & $\begin{array}{l}\mathrm{NO}_{3} \\
(\mu \mathrm{M})\end{array}$ & $\begin{array}{l}\mathrm{NH}_{4} \\
(\mu \mathrm{M})\end{array}$ & $\begin{array}{c}\mathrm{Fe} \\
(\mu \mathrm{M})\end{array}$ & $\begin{array}{c}\mathrm{H}_{4} \mathrm{SiO}_{4} \\
(\mu \mathrm{M})\end{array}$ & $\underset{(\mu \mathrm{M})}{\mathrm{Li}}$ & $\underset{(\mu \mathrm{M})}{\mathrm{Sr}}$ \\
\hline Surface seawater & - & 8.2 & 2.35 & 11.05 & 56.8 & 590 & 30.5 & 0 & 5 & - & 0 & 27 & 97 \\
\hline BAW-1 & 3.5 & 6.88 & 5.35 & 12.17 & 55.4 & 576 & 28.5 & 12.5 & 36 & ${ }^{a} 167$ & 31 & - & - \\
\hline BAW-2-A & $19-22$ & 7.69 & 1.66 & 47.0 & 39.1 & 585 & 28.0 & 3 & 4 & 0 & 130 & - & 153 \\
\hline BAW-2-B & - & 8.07 & 1.65 & 48.7 & 37.6 & 585 & 27.5 & 4 & 6 & - & 142 & 144 & 162 \\
\hline BAW-2 (overflow) & - & - & - & 32.6 & 27.8 & 425 & 19.4 & - & 10 & - & 50 & - & - \\
\hline BAW-2 (corrected to $\mathrm{Cl}=585$ ) & - & - & - & 44.9 & 38.3 & (585) & 26.7 & - & - & - & 69 & - & - \\
\hline Bottom water & 1.8 & - & - & 10.50 & 53.8 & $b_{556}$ & 28.8 & $c_{22.5}$ & - & - & $b_{55}$ & - & - \\
\hline Standard seawater & - & & & 10.55 & 54.0 & 559 & 28.9 & - & - & - & - & - & 92 \\
\hline
\end{tabular}

${ }^{\text {a }}$ Sample showed visible precipitation of $\mathrm{Fe}(\mathrm{OH})_{3}$.

${ }^{b}$ Estimated from Broecker and Peng (1983).

${ }^{\mathrm{c}}$ Estimated from Broecker and Peng (1983) and Geosecs data.

Table 2. Strontium isotope ratios of formation water, Hole 418A.

\begin{tabular}{lccccl}
\hline Sample & $\begin{array}{c}\text { Depth } \\
(\mathrm{m})\end{array}$ & $\begin{array}{c}\mathrm{Rb} \\
(\mu \mathrm{M})\end{array}$ & $\begin{array}{c}\mathrm{Cs} \\
(\mathrm{nM})\end{array}$ & $\begin{array}{c}\mathrm{Sr} \\
(\mu \mathrm{M})\end{array}$ & \multicolumn{1}{c}{${ }^{87} \mathrm{Sr} /{ }^{86} \mathrm{Sr}$} \\
\hline 102-2B & ${ }^{\mathrm{a}} 325$ & 1.317 & 1.979 & 147 & $0.707794 \pm 0.000023$ \\
bSurface water & 0 & 1.226 & 2.265 & 87 & 0.70912
\end{tabular}

Note: Isotope dilution concentrations; isotope standard EA 0.70800 .

a Depth within basement.

${ }^{b}$ Hole 504B surface water (Hart and Mottl, 1983).

pipe show little evidence of downward water displacement during lowering of the tool (Shipboard Scientific Party, 1986). Thus it can be safely assumed that a valid sample was obtained.

Of interest is the observation of a substantial amount of dissolved iron, presumably from iron contamination in the cased section by corrosive release from the casing. It is possible that either downward mixing of pipe water occurred prior to reentry or such mixing was induced by the lowering of the pipe and the tool. Lowering only the pipe would cause little mixing because the outside diameter of the pipe is considerably smaller than the inside diameter of the casing (G. Foss, pers. comm., 1985). However, the Barnes-Uyeda tool could have pushed down some pipe water, although presumably little. For instance, very good samples were obtained under similar operating conditions during Leg 92 (Gieskes et al., 1986). Therefore, we will assume that a pristine water sample was taken.

The chlorosity of the sample is between that of surface and bottom water. Similarly dissolved $\mathrm{NO}_{3}$ is, at $12.5 \mu \mathrm{M}$, about $50 \%$ of the bottom-water concentration. Dissolved silica is also about $50 \%$ of the bottom-water concentration. Using the $50 \%$ proportion, we calculate a chlorosity of $\mathrm{Cl}=573 \mathrm{mM}$, close to the observed value of $\mathrm{Cl}=576 \mathrm{mM}$.

If the reentry operation did not cause the downhole mixing, another mechanism must have been involved. Surface seawater left in the hole when it was abandoned $8 \mathrm{yr}$ ago was presumably at about the same temperature as bottom water, but with a much greater salinity and hence, higher density. Density would gradually decrease with depth following establishment of the geothermal gradient in the hole. This, in turn, could have led to slow convective mixing, as has been discussed by Luheshi (1983).
Whether less-dense bottom water could have been entrained by such mixing has not been determined but deserves evaluation, especially because this process has been invoked to explain smooth concentration-depth gradients in Hole 504B (Gieskes et al., 1986).

The slightly increased $\mathrm{Ca}^{2+}$ concentration is matched by that in alkalinity and is probably the result of $\mathrm{CaCO}_{3}$ dissolution at the relatively low $\mathrm{pH}$ of the water. A change in $\mathrm{Mg}^{2+}$, if any, is insignificant.

Again, the sample does not indicate any significant change in major ion chemistry, but $\mathrm{NO}_{3}^{-}, \mathrm{H}_{4} \mathrm{SiO}_{4}$, and $\mathrm{Cl}^{-}$concentrations suggest possible downhole mixing of bottom water throughout the hole's existence. Indeed, the lack of any sediment signal in the water chemistry, with the possible exception of a minor increase in ammonia, suggests that reintroduction of pipe may have collapsed sediment, and the hole was essentially open in this zone for the last $8 \mathrm{yr}$. We do not see any evidence that actual downhole flow of water has occurred in the past.

\section{Sample BAW-2}

Circumstances dictated only one chance to obtain basement water, therefore, we decided to obtain a sample at about $325 \mathrm{~m}$ within the basement. During lowering of the pipe, surface seawater was pumped down vigorously to clear debris from the hole in preparation for logging operations. Pumping was halted about $50 \mathrm{~m}$ above the sampling depth. Temperature measurements, however, indicated prevailing temperatures $\left(19^{\circ}-22^{\circ} \mathrm{C}\right)$ lower than that predicted from the geothermal gradient, $23.5^{\circ} \mathrm{C}$ (Shipboard Scientific Party, 1986). This is presumably due to some downhole mixing caused by the vigorous pumping of seawater. Thus, any deviation from seawater composition may have been larger in situ, and our reported changes could represent minimum values.

An intriguing problem is the small amount of $\mathrm{NO}_{3}^{-}$present in the sample. Surface waters generally have little or no nitrate present; therefore, the nitrate concentration could indicate downhole mixing of bottom waters to the extent that $10 \%-15 \%$ of the originally pumped-in surface water was replaced by bottom water. This would mean that the hole must have been open for a considerable amount of time before sediment collapse sealed it off. Sample BAW-1 certainly appears to show evidence for down-

Table 3. Differences in concentration between deep borehole waters of Hole $418 \mathrm{~A}$ and surface seawater.

\begin{tabular}{lccccccccc}
\hline Sample & $\begin{array}{c}\Delta \mathrm{Ca} \\
(\mathrm{mM})\end{array}$ & $\begin{array}{c}\Delta \mathrm{Mg} \\
(\mathrm{mM})\end{array}$ & $\Delta \mathrm{Ca} / \Delta \mathrm{Mg}$ & $\begin{array}{c}\Delta \mathrm{Cl} \\
(\mathrm{mM})\end{array}$ & $\begin{array}{c}\Delta \mathrm{SO}_{4} \\
(\mathrm{mM})\end{array}$ & $\begin{array}{c}\Delta \mathrm{NO}_{3} \\
(\mu \mathrm{M})\end{array}$ & $\begin{array}{c}\Delta \mathrm{H}_{4} \mathrm{SIO}_{4} \\
(\mu \mathrm{M})\end{array}$ & $\begin{array}{c}\Delta(\mathrm{Na}+\mathrm{K})^{\mathrm{a}} \\
(\mathrm{mM})\end{array}$ & $\begin{array}{c}\Delta \mathrm{K} \\
(\mathrm{mM})\end{array}$ \\
\hline BAW-2-A & +36.0 & -17.7 & -2.03 & -5 & -2.5 & +3 & +130 & -48 & -2.6 \\
BAW-2-B & +37.7 & -19.0 & -1.98 & -5 & -2.9 & +4 & +140 & -48 & -3.5 \\
\hline
\end{tabular}

${ }^{\text {a }}$ By charge-balance calculation. 
hole mixing. Unfortunately, we do not have a precise estimate for the chlorinity of either the originally introduced surface seawater or the original dissolved nitrate, but the slightly lower $\mathrm{Cl}=585 \mathrm{mM}$ in BAW-2, in comparison with present surfaceseawater chlorinity of $\mathrm{Cl}=590 \mathrm{mM}$, is compatible with a $10 \%$ bottom-water component. Naturally, these arguments are highly speculative.

The most striking feature of the water-sample chemistry is the relatively large increase in $\mathrm{Ca}^{2+}$ in comparison with the decrease in $\mathrm{Mg}^{2+}$. The ratio of the concentration changes is $\Delta \mathrm{Ca}$ / $\Delta \mathrm{Mg} \sim-2.0$, which is much lower than that observed at either Site 417 or Site 418 (Fig. 2). In addition, the decrease in $\mathrm{SO}_{4}^{2-}$ is very small (Table 2), which is again much smaller than that observed at Sites 417 and 418 . At these sites we observed $\Delta \mathrm{SO}_{4}^{2-}=$ -7 to $-8 \mathrm{mM}$ (Gieskes and Reese, 1980). In part, this difference can be explained in terms of sulfate-reduction processes, which affect sulfate concentrations in the sediment column but not necessarily the originally trapped seawater in the basalt. Any associated calcium carbonate precipitation would tend to diminish the increase in dissolved calcium, thus also explaining the difference in the $\Delta \mathrm{Ca} / \Delta \mathrm{Mg}$ ratios. However, as a first approximation the concentration gradients of $\mathrm{Ca}^{2+}$ and $\mathrm{Mg}^{2+}$ are conservative in the sediment column, which minimizes the effect of calcium carbonate precipitation. Of course, there is no a priori reason why all the basalt formation waters of Site 418 should have a uniform composition.

From an application of charge-balance calculations, a decrease of about $48 \mathrm{mM}$ in $\left(\mathrm{Na}^{+}+\mathrm{K}^{+}\right)$is expected (Table 3), of which $\Delta \mathrm{K}^{+}$is about $-3 \mathrm{mM}$. This observation is consistent with those from charge-balance calculations at many sites (including Sites 417 and 418), in which $\Delta \mathrm{Ca} / \Delta \mathrm{Mg}<-1$ (McDuff, 1981; Gieskes, 1983).

The concentration of $\mathrm{Li}^{+}$is elevated, as is that of dissolved silica. Of special interest is the fairly large increase in dissolved $\mathrm{Sr}^{2+}$ as well as the low ${ }^{87} \mathrm{Sr} /{ }^{86} \mathrm{Sr}$ ratio of dissolved strontium (Table 2). The strontium increases relative to calcium are larger at Site 418 than in Hole 504B (Mottl et al., 1985; Gieskes et al., 1986), perhaps because of the formation of anhydrite in the downhole waters of Hole 504B. Our data indicate that $\mathrm{CaSO}_{4}$ precipitation in Hole 418A borehole fluids is negligible.

In the following, we discuss two scenarios that may explain our observations: reaction between seawater in the hole with the surrounding rocks and diffusive exchange with the formation waters in the surrounding basalt.

\section{Reaction in the Hole}

Though reaction rates involving basalt alteration should be extremely small at low temperatures, it is possible that reaction occurred with volcanic material either suspended in the hole or in the borehole wall. One would expect the reaction to occur at high water/rock ratios. Indeed, assuming a basalt $\mathrm{CaO}$ content of $12 \%$ and a $\mathrm{Ca}^{2+}$ increase of $37 \mathrm{mM}$ in the solution, a water/ rock ratio of about 58 is obtained. This estimate assumes no precipitation of $\mathrm{CaCO}_{3}$ or any other Ca-mineral phase. Significant precipitation of carbonate is ruled out because of the low alkalinity of the surface water. Of course, the above calculation assumes complete release of all $\mathrm{Ca}^{2+}$ by the rock. If only $10 \%$ of the rock is altered, a more common percentage observed in bulk chemical analyses, the actual water/rock ratio would be 6 or perhaps lower. If this is true, then for every cubic decimeter of water about $0.17 \mathrm{~kg}$ of rock must have undergone alteration, or about $65 \mathrm{~cm}^{3}$ of rock. In a hole about $30-\mathrm{cm}$ diameter, a $1-\mathrm{cm}$ thick vertical layer would require about $45 \mathrm{~cm}^{3}$ of rock to be altered by $10 \%$. This implies that only about $1.5 \mathrm{~cm}$ of the surrounding basalts were altered. Of course, this is purely a massbalance calculation, and for complete alteration (and total loss of $\mathrm{CaO}$ ) a much thinner layer of rock is required. At these high water/rock ratios the effect on the $\delta^{18} \mathrm{O}$ of the borehole water would hardly be noticeable (Lawrence et al., 1975) and would cause a change of no more than $-0.5 \%$, and probably less.

Unfortunately, very little is known about the quantitative aspects of ion exchange during low-temperature alteration of basaltic materials, at least in an experimental setting. There is no doubt that $\mathrm{Ca}^{2+}$ is released and $\mathrm{CaCO}_{3}$ is precipitated during early alteration of basalt, especially when fresh water flows through basalt at high water/rock ratios, thereby supplying a source of $\mathrm{CO}_{3}{ }^{2-}$ ions for $\mathrm{CaCO}_{3}$ precipitation. Debate exists as to whether $\mathrm{Mg}^{2+}$ is released or taken up by the rock during early alteration, but the loss of dissolved $\mathrm{K}^{+}$is well recorded. Little evidence exists on the fate of $\mathrm{Na}^{+}$and $\mathrm{Li}^{+}$. McDuff's (1981) analysis of DSDP interstitial-water $\mathrm{Ca}^{2+}$ and $\mathrm{Mg}^{2+}$ gradients found that sites in younger crust often show $\Delta \mathrm{Ca}^{2+} / \Delta \mathrm{Mg}^{2+}>$ -1 (c.f., his observation for Site 395; McDuff, 1984). Over time, and with the total disappearance of $\mathrm{Mg}^{2+}$ in the underlying basement, this ratio will be less than -1.0 , as is the case in the interstitial waters of Sites 417 and 418 (Gieskes and Reese, 1980). The correlation in the BAW-2 sample yields a ratio of $\Delta \mathrm{Ca}^{2+} / \Delta \mathrm{Mg}^{2+}=-2$. This high ratio would classify the changes in $\mathrm{Ca}^{2+}$ and $\mathrm{Mg}^{2+}$ under "older" sites or, rather, under sites with a complete depletion of $\mathrm{Mg}^{2+}$.

Even though we cannot rule out a priori that interactions occur between borehole waters and the surrounding rocks, we prefer to explain the changes observed in the chemical composition of the borehole fluids as a result of exchange by diffusive transport with formation waters in the surrounding rocks of Layer 2.

\section{Exchange with Surrounding Rocks}

Prior to discussing the possibility of exchange by transport of dissolved constituents from or into the potential pore-water reservoir in the surrounding rocks, it is appropriate to estimate whether diffusive processes could be the main cause for the exchange.

If the "average" porosity of the formation is between $5 \%$ and $10 \%$, the bulk diffusion coefficient can be approximated by the formula

$$
\mathrm{D}_{\mathrm{b}}=\mathrm{p}^{2} \mathrm{D}_{\mathrm{o}},
$$

where $\mathrm{p}=$ porosity and $\mathrm{D}_{\mathrm{o}}=$ pure diffusion coefficient $\left(\sim 10^{-5} \mathrm{~cm}^{2} / \mathrm{s}\right)$. For the previously mentioned porosity values, this yields $D_{b}=0.3 \times 10^{-7} \mathrm{~cm}_{b}^{2} / \mathrm{s}$ to $1.0 \times 10^{-7} \mathrm{~cm}_{b}^{2} / \mathrm{s}$, where the subscript b denotes the bulk formation. McDuff (1984) assumed a value of $10^{-6} \mathrm{~cm}_{\mathrm{b}}{ }^{2} / \mathrm{s}$ for Site 395 , corresponding to a porosity of $30 \%$.

The range of diffusion coefficients from $0.3 \times 10^{-7} \mathrm{~cm}_{\mathrm{b}}{ }^{2} / \mathrm{s}$ to $1.0 \times 10^{-7} \mathrm{~cm}_{\mathrm{b}}{ }^{2} / \mathrm{s}$ yields an average diffusive path length $\mathrm{x}=\left(2 \mathrm{D}_{\mathrm{b}} \mathrm{t}\right)^{1 / 2}$ of 4-7 $\mathrm{cm}_{\mathrm{b}}$ over the 8 -yr period since the drilling of the hole.

McDuff (1984) solved the diffusion equation for assumed diffusion from a porous bed into a well-stirred reservoir (the hole) to derive a relation between the concentration in the hole and in the formation (Crank, 1970):

$$
C_{\text {hole }}=\left(C_{\text {formation }}-C_{\text {initial }}\right)(1-\exp \Omega \operatorname{erfc} \Omega)+C_{\text {initial }} \text {, }
$$

where $\Omega=D_{b} t / r^{2}<1$ and $r$ is the radius of the hole. Applying this formula for the dissolved calcium we obtain

$$
\text { for } \begin{aligned}
\mathrm{D}_{\mathrm{b}}=10^{6} \mathrm{~cm}_{\mathrm{b}}{ }^{2} / \mathrm{c} & \mathrm{C}_{\text {formation }}=85 \mathrm{mM} \\
\mathrm{D}_{\mathrm{b}}=10^{-7} \mathrm{~cm}_{\mathrm{b}}{ }^{2} / \mathrm{c} & \mathrm{C}_{\text {formation }}=130 \mathrm{mM} \\
\mathrm{D}_{\mathrm{b}}=3 \times 10^{-8} \mathrm{~cm}_{\mathrm{b}}{ }^{2} / \mathrm{c} & \mathrm{C}_{\text {formation }}=210 \mathrm{mM}
\end{aligned}
$$

These concentrations do not appear to be impossible, especially in view of our own observations of sediments intercalated in basalt (e.g., Site 446, Gieskes and Johnson, 1981, 120 mM; Site 
528, Gieskes et al., 1984, $80 \mathrm{mM}$ ). In the aforementioned cases, concentration gradients in the overlying sediments were diffusive in nature, therefore, diffusive transport through sediment could explain the essentially linear gradients. Thus it is indeed possible that a large portion of the calcium signal does stem from transport processes with the surrounding rocks rather than reaction with borehole waters.

The preceding calculation presents a two-dimensional case. If significant convection were to take place in the hole, then a gradient might occur, and a more complex model should be introduced. However, with only one sample available, we are forced to rely on the two-dimensional model.

Increases in chloride have often been observed in sediment pore waters in conjunction with large changes in $\mathrm{Ca}^{2+}$, presum- ably as a result of water loss to alteration minerals. Thus, the presence of a $\mathrm{Cl}^{-}$concentration similar to that of surface seawater may not necessarily mean that there was no exchange with the surrounding rocks.

\section{Estimated Formation-Water Composition}

If diffusive exchange with the surrounding rocks has caused the observed increases in $\mathrm{Ca}^{+}$and decreases in $\mathrm{Mg}^{2+}$ and if the complete depletion of $\mathrm{Mg}^{2+}$ is implied by a $\Delta \mathrm{Ca}^{2+} / \Delta \mathrm{Mg}^{2+}$ ratio lower than -1 , we should be able to estimate the chemical composition of the formation water end-member by extrapolation of the data to $\mathrm{Mg}^{2+}=0 \mathrm{mM}$ (Fig. 4). Table 4 presents the calculated end-member concentrations.

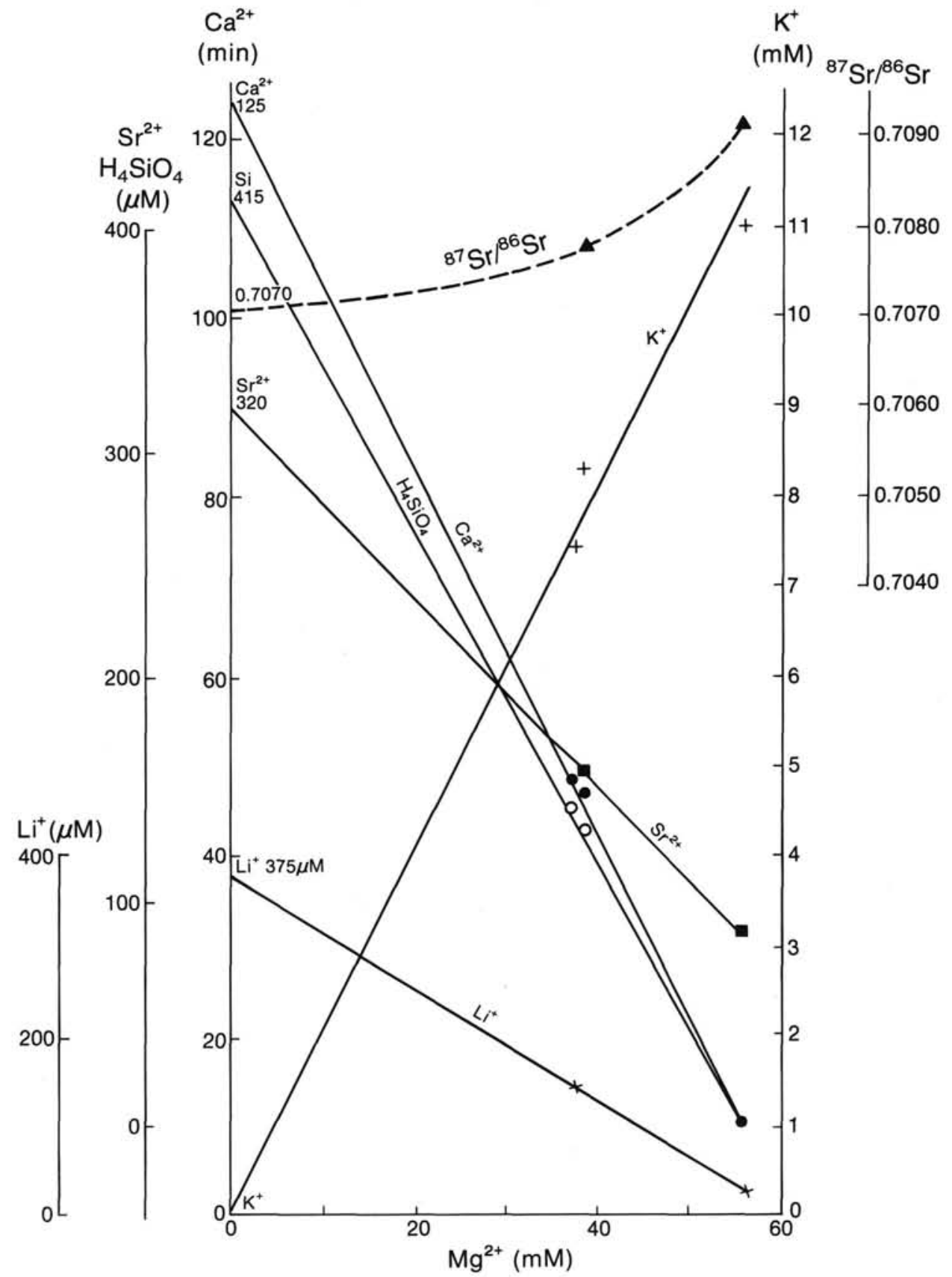

Figure 4. Extrapolation of $\mathrm{Ca}^{2+}, \mathrm{Sr}^{2+},{ }^{87} \mathrm{Sr} /{ }^{86} \mathrm{Sr}, \mathrm{Li}^{+}, \mathrm{K}^{+}$, and $\mathrm{H}_{4} \mathrm{SiO}_{4}$ to $\mathrm{Mg}^{2+}=0 \mathrm{mM}$. 
Table 4. Estimated endmember concentrations of formation fluids, Hole 418A.

\begin{tabular}{lr}
\hline End-member & Concentration \\
\hline $\mathrm{Li}^{+}$ & $375 \mu \mathrm{M}$ \\
$\mathrm{Na}^{+}$ & $395 \mathrm{mM}$ \\
$\mathrm{K}^{+}$ & $0 \mathrm{mM}$ \\
$\mathrm{Ca}^{2+}$ & $125 \mathrm{mM}$ \\
$\mathrm{Mg}^{2+}$ & $0 \mathrm{mM}$ \\
$\mathrm{Sr}^{2+}$ & $320 \mu \mathrm{M}$ \\
$87 \mathrm{Sr}^{86} \mathrm{Sr}$ & 0.7070 \\
$\mathrm{SO}_{4}^{2-}$ & $22 \mathrm{mM}$ \\
$\mathrm{H}_{4} \mathrm{SiO}_{4}$ & $415 \mu \mathrm{M}$ \\
\hline
\end{tabular}

The extrapolated $\mathrm{Ca}^{2+}$ concentration is in reasonable agreement with the estimate from the diffusion model, assuming a rock porosity of $10 \%$. The fact that the $\mathrm{K}^{+}$data also extrapolate to zero concentration lends support to the validity of the extrapolation. The sulfate concentration, on the other hand, is surprisingly high. The product of $\mathrm{Ca}^{2+} \times \mathrm{SO}_{4}^{2-}$ is about $2750(\mathrm{mM})^{2}$, which is considerably higher than the product expected from gypsum solubility at $25^{\circ} \mathrm{C}$ and atmospheric pressure for the ionic strength of seawater (ca. 1300 (mM) ${ }^{2}$; Marshall and Slusher, 1966; Harvie and Weare, 1980). Pressure and temperature effects both lead to higher solubility, but we do not expect these effects to be large enough to account for the difference. Perhaps kinetic factors prevent the precipitation of gypsum or anhydrite.

The extrapolated ${ }^{87} \mathrm{Sr} /{ }^{86} \mathrm{Sr}$ ratio is 0.7070 , lower than contemporaneous seawater at the time of basalt emplacement at Site 418 (ca. 0.7074; Staudigel and Hart, 1985) and much lower than that of present-day seawater $(0.70915)$. We conclude that a contribution of nonradiogenic strontium from basalt is indicated $\left({ }^{87} \mathrm{Sr} /{ }^{86} \mathrm{Sr}=0.703\right)$. Staudigel and Hart $(1985)$ studied the strontium isotope ratios of vein calcite and smectites in Hole $418 \mathrm{~A}$ ( 0.7070 to 0.7076 for calcites, 0.70578 and higher for smectites). Many of their data show ratios less than that of contemporaneous seawater, again indicating basalt as a partial source for nonradiogenic strontium.

The data in Table 4 also indicate an increase in $\mathrm{Li}^{+}(376 \mu \mathrm{M})$ and dissolved silica $(400 \mu \mathrm{M})$. Even though the alkali metals $\mathrm{K}^{+}$ and, to a large extent, $\mathrm{Na}^{+}$are removed, $\mathrm{Li}^{+}$is released. Of the other alkali metals, we note a slight increase in $\mathrm{Rb}^{+}$but a significant decrease in $\mathrm{Cs}^{+}$(Table 2).

\section{COMPARISON WITH OTHER STUDIES}

Studies reported here of the borehole-fluid chemistry at Hole 418A constitute the third attempt to infer the composition of formation waters in basalt. In Table 5 we represent the suggested end-member compositions obtained from an extrapolation of the data to zero magnesium concentrations. The legitimacy of this procedure may be questioned, especially because there is no a priori reason why reactions in basalt will not continue beyond this point. Indeed, pore-water gradients of $\mathrm{Ca}^{2+}$ continue beyond the point of $\mathrm{Mg}^{2+}$ depletion at Site 446 (Gieskes and Johnson, 1980). However, for comparative purposes this extrapolation can be useful.

McDuff (1984) argues that too little time has elapsed since the introduction of surface water in Hole 395 to allow any significant reaction with the wall rocks. In addition, McDuff (1984) suggests that the end-member concentration may well not have a zero $\mathrm{Mg}^{2+}$ concentration, especially if the residence time of the formation waters has been relatively short. A major problem with the Hole 395 data appears to be the small increase in calcium and the large decrease in sulfate. McDuff (1984) ex-
Table 5. Inferred basement formation-water composition, Holes 395, 418A, and 504B.

\begin{tabular}{llccc}
\hline \multicolumn{1}{c}{ Element } & $\begin{array}{l}\text { Seawater } \\
(\mathrm{S}=35)\end{array}$ & $395^{\mathrm{a}}$ & $418 \mathrm{~A}^{\mathrm{b}}$ & $504 \mathrm{~B}^{\mathrm{c}}$ \\
\hline $\mathrm{Ca}(\mathrm{mM})$ & 10.55 & 13.5 & 125 & 130 \\
$\mathrm{~d} \mathrm{Mg}(\mathrm{mM})$ & 54.0 & 0 & 0 & 0 \\
$\mathrm{~K}(\mathrm{mM})$ & 10.5 & 3.5 & 0 & 4.5 \\
$\mathrm{Na}(\mathrm{mM})$ & 453 & 500 & 395 & 418 \\
$\mathrm{Sr}(\mu \mathrm{M})$ & 86 & 105 & 320 & 86 \\
${ }^{87} \mathrm{Sr} / 86 \mathrm{Sr}$ & 0.70915 & - & 0.7070 & ${ }^{\mathrm{d}} 0.70723$ \\
$\mathrm{SO}_{4}^{2-}(\mathrm{mM})$ & 28.9 & 12 & 20 & 7 \\
\hline
\end{tabular}

a McDuff, 1984.

b This report.

c Mottl et al. (1985) and Gieskes et al. (1986).

d All data extrapolated to $\mathrm{Mg}^{2+}=0 \mathrm{mM}$.

plains the former in terms of $\mathrm{CaCO}_{3}$ precipitation, with the $\mathrm{HCO}_{3}^{-}$stemming from percolating seawater. However, in this case relatively little $\mathrm{Ca}^{2+}$ needs to be produced from the basalt, especially in comparison to the relatively large decreases in $\mathrm{Mg}^{2+}$ and $\mathrm{K}^{+}$. An additional problem is the large decrease in $\mathrm{SO}_{4}^{2-}$, which is difficult to explain on the basis of sulfate reduction in the overlying sediments prior to introduction into the underlying basalt. The sediment of Site 395 does not show such a large decrease in sulfate. An alternative explanation is that the fluids in the formation carry a substantial component of deeper-seated waters, which may have experienced higher temperatures. This could, for instance, have been associated with the deeper-seated sill intrusion that caused gypsum precipitation in the form of a vein mineral (Lawrence et al., 1979), which accounts for the relatively large depletion in sulfate and the small increase in calcium. If the data of McDuff (1984) are extrapolated to $\mathrm{K}^{+}=0 \mathrm{mM}$, then the $\mathrm{SO}_{4}^{2-}$ concentration becomes zero also.

As mentioned before, interpretation of the Hole 504B data is still speculative (Mottl et al., 1983, 1985; McDuff, 1984; Gieskes et al., 1986). There is no doubt that alteration of volcanic matter contributes to the observed chemical changes, but we cannot establish a priori how much reaction occurs with the glass present in the pumped-down bentonite or from the wall rocks or how much is due to exchange with the formation waters from the surrounding basalts. Of some interest is the observation that the concentration gradients of $\mathrm{Ca}^{2+}$ and $\mathrm{Mg}^{2+}$ in the upper part of Hole 504B were considerably less pronounced than during the previous investigation (Mottl et al., 1985). If diffusion from the surrounding formation is indeed important, then refilling the hole with fresh seawater would cause less mass transfer from the depleted formation. The reentry of Hole 504B during ODP Leg 111 may shed further light on this problem. At greater depths in the hole, formation porosity becomes less than $3 \%$ (Becker et al., 1985). It is not known if diffusive exchange would still play an important role under such circumstances.

The Hole 418A data suggest that a very good case can be made for diffusive exchange in this hole with the surrounding basement formation. Unfortunately, no data were obtained for $\delta^{18} \mathrm{O}$ of the fluids, but the ${ }^{87} \mathrm{Sr} /{ }^{86} \mathrm{Sr}$ data are the lowest yet recorded and indicate exchange with the underlying basalts. Unfortunately, only one sample of downhole water was obtained from Hole 418A during Leg 102. In the future, it is imperative to obtain a series of samples to establish potential concentration gradients.

\section{ACKNOWLEDGMENTS}

Russ McDuff and Michael Mottl reviewed the manuscript. The author wishes to thank USSAC for the support of this research. The shipboard logging party tolerated a geochemist in their midst, which gives us hope for the future. 


\section{REFERENCES}

Anderson, R. H., Langseth, M. G., and Sclater, J. G., 1977. The mechanism of heat transfer through the floor of the Indian Ocean. $J$. Geophys. Res., 82:3391-3409.

Becker, K., Langseth, M. G., and Hyndman, R. D., 1984. Temperature measurements in Hole 395A, Leg 78B. In Hyndman, R. D., Salisbury, M. H., et al., Init. Repts. DSDP, 78B: Washington (U.S. Govt. Printing Office), 689-698.

Becker, K., Langseth, M. G., Von Herzen, R., Anderson, R. N., and Hobart, M. A., 1985. Deep crustal geothermal measurements, Hole 504B, DSDP Legs 69, 70, 83, and 92. In Anderson, R. N., Honnorez, J., and Becker, K., et al., Init. Repts. DSDP, 83: Washington (U.S. Govt. Printing Office), 405-418.

Broecker, W. S., and Peng, T. H., 1983. Tracers in the Sea: Palisades, NY (Eldigio Press).

Crank, J., 1970. The Mathematics of Diffusion (1st ed., rev.): London (Oxford University Press).

Gieskes, J. M., 1974. Interstitial water studies, Leg 25. In Simpson, E.S.W., Schlich, R., et al., Init. Repts. DSDP, 25: Washington (U.S. Govt. Printing Office), 361-394.

1983. The chemistry of interstitial waters of deep sea sediments; Interpretation of Deep Sea Drilling data. Chem. Oceanogr., 8:221-269.

Gieskes, J. M., and Johnson, J., 1981. Interstitial water studies, Leg 58. In Larson, R. L., Schlanger, S. O., et al., Init. Repts. DSDP, 61: Washington (U.S. Govt. Printing Office), 607-611.

Gieskes, J. M., and Johnston, K., 1984. Interstitial water studies, Leg 81. In Roberts, D. G., Schnitker, D., et al., Init. Repts. DSDP, 81: Washington (U.S. Govt. Printing Office), 829-836.

Gieskes, J. M., Johnston, K., and Boehm, M., 1984. Interstitial water studies, Leg 74. In Moore, T. C., Jr., Rabinowitz, P. D., et al., Init. Repts. DSDP, 74: Washington (U.S. Govt. Printing Office), 701711.

Gieskes, J. M., Kastner, M., Erzinger, J., Boulegue, J., and Hart, S. R., 1986. Geochemical studies in Hole 504B, Leg 92. In Leinen, M., Rea, D. K., et al., Init. Repts. DSDP, 92: Washington (U.S. Govt. Printing Office), 547-562.

Gieskes, J. M., and Lawrence, J. R., 1981. Alteration of volcanic matter in deep sea sediments: Evidence from the chemical composition of interstitial waters from deep sea drilling cores. Geochim. Cosmochim. Acta, 45:1687-1703.

Gieskes, J. M., and Peretsman, G., 1986. Water chemistry procedures aboard JOIDES Resolution-some comments. Ocean Drilling Program Tech. Note, 5.

Gieskes, J. M., and Reese, H., 1980. Interstitial water studies, Legs 5153. In Donnelly, T., Francheteau, J., Bryan, W., Robinson, P., Flower, M., Salisbury, M., et al., Init. Repts. DSDP, 51, 52, 53, Pt. 2: Washington (U.S. Govt. Printing Office), 747-751.

Hart, S. R., and Mottl, M. J., 1983. Alkali and Sr isotope geochemistry of waters collected from basaltic basement, DSDP Hole 504B, Costa Rica Rift. In Cann, J. R., Langseth, M. G., Honnorez, J., Von Herzen, R. P., White, S. M., et al., Init. Repts. DSDP, 69: Washington (U.S. Govt. Printing Office), 487-494.

Harvie, C. D., and Weare, J. H., 1980. The prediction of mineral solubilities in natural waters: the $\mathrm{Na}-\mathrm{K}-\mathrm{Mg}-\mathrm{Ca}-\mathrm{Cl}-\mathrm{SO}_{4}-\mathrm{H}_{2} \mathrm{O}$ system from zero to high concentrations. Geochim. Cosmochim. Acta, 44:981997.

Lawrence, J. R., Drever, J. J., and Kastner, M., 1979. Low temperature alteration of basalts predominates at DSDP Site 395. In Melson, W. G., Rabinowitz, P. D., et al., Init. Repts. DSDP, 45: Washington (U.S. Govt. Printing Office), 609-612.

Lawrence, J. R., and Gieskes, J. M., 1981. Constraints on water transport and alteration in the oceanic crust from the isotopic composition of pore water. J. Geophys. Res., 86:7924-7934.

Lawrence, J. R., Gieskes, J. M., and Broecker, W. S., 1975. Oxygen isotope and cation composition of DSDP pore waters and alteration of Layer 2 basalts. Earth Planet. Sci. Lett., 27:1-10.

Luheshi, M. N., 1983. Estimation of formation temperature from bore hole measurements. Geophys. J. R. Astron. Soc., 74:749-776.

Marshall, W. L., and Slusher, R., 1966. Thermodynamics of calcium sulfate dihydrate in aqueous sodium chloride solutions, $0-100^{\circ} . \mathrm{J}$. Phys. Chem., 70:4015-4027.

McDuff, R. E., 1978. Conservative behavior of calcium and magnesium in the interstitial waters of marine sediments: identification and interpretation [Ph.D. dissert.]. University of California, San Diego. 1981. Major cation gradients in DSDP interstitial waters; the role of diffusive exchange between seawater and upper ocean crust. Geochim. Cosmochim. Acta, 45:1705-1713. 1984. The chemistry of interstitial waters from the upper ocean crust, Site 395, DSDP Leg 78B. In Hyndman, R. D., Salisbury, M. H., et al., Init. Repts. DSDP, 78B: Washington (U.S. Govt. Printing Office), 795-799.

Mottl, M. J., Anderson, R. N., Jenkins, W. J., and Lawrence, J. R., 1983. Chemistry of waters sampled from basaltic basement in DSDP Holes 501, 504B and 505B. In Cann, J. R., Langseth, M. G., Honnorez, J., Von Herzen, R. P., White, S. M., et al., Init. Repts. DSDP, 69: Washington (U.S. Govt. Printing Office), 475-484.

Mottl, M. J., Druffel, E. M., Hart, S. M., Lawrence, J. R., and Caltzman, E., 1985. Chemistry of hot water sampled from basaltic basement in Hole 504B, Deep Sea Drilling Project Leg 83, Costa Rica Rift. In Anderson, R. N., Honnorez, J., Becker, K., et al., Init. Repts. DSDP, 83: Washington (U.S. Govt. Printing Office), 315330 .

Muehlenbachs, K., and Clayton, R. N., 1976. Oxygen isotope composition of the oceanic crust and its bearing on sea water. J. Geophys. Res., 82:4365-4369.

Shipboard Scientific Party, 1986. Site 418: Bermuda Rise. In Salisbury, M. H., Scott, J. H., et al., Proc. ODP, Init. Repts., 102: College Station, TX (Ocean Drilling Program), 95-149.

Staudigel, H., and Hart, S. R., 1985. Dating of oceanic crust hydrothermal alteration: strontium isotope ratios from Site 504B carbonates and reinterpretation of Sr-isotope data from DSDP Sites 105, 332, 417 and 418. In Anderson, R. N., Honnorez, J., Becker, K., et al., Init. Repts. DSDP, 83: Washington (U.S. Govt. Printing Office), 297-303.

Date of initial receipt: 13 March 1987

Date of acceptance: 31 July 1987

Ms 102B-120 